\title{
Public health and the potential benefits of Crime Prevention Through Environmental Design
}

\section{Paul Cozens}

Department of Urban and Regional Planning,

Curtin University of Technology

Email:p.cozens@curtin.edu.au

\begin{abstract}
Studies have consistently found that safety and security are major public concerns; however, crime is rarely considered as an outcome in public health. The recent shift by planning policy towards promoting compact, 'walkable' communities close to public transport aims to redress many of the problems associated with urban sprawl. However, communities that do not feel safe are less likely to be active citizens. This paper argues that Crime Prevention Through Environmental Design has potential benefits for public health in the provision of local crime risk assessments and in delivering safer environments, which can support active living, walkable communities and public health.
\end{abstract}

Human settlements have always sought to provide for the safety, security and the well-being of their residents. However, industrialisation and urbanisation created a range of new threats to public health and well-being. The rapid, unplanned and 'laissez faire' expansion of cities in the 20th century resulted in overcrowding, pollution, poverty, disease, 'anomie' 1 and crime, with cities becoming locations of problems as well as places of vitality and excitement.

Today, crime is still a public health problem and studies consistently find that safety and security are the first priority of the urban poor. ${ }^{2,3}$ In Australia, the financial costs of crime to the community have been estimated to be approximately $\$ 32$ billion per annum ${ }^{4}$ and studies consistently reveal that significant sections of the community are fearful for their personal safety when using or visiting the city. ${ }^{5}$

Crime and the fear of crime are not evenly distributed throughout the city either spatially or temporally, and the notion of 'hot spots' of crime (where/when crime and/or the fear of crime are highly concentrated) has received increasing attention in recent years. ${ }^{6-9}$
Crime and public health issues have similar origins ${ }^{10}$ and outcomes can be improved using similar approaches (e.g. improving socio-economic conditions and enhancing social capital). The effect of the built environment on crime and public health indicates that its design and modification can be used as an effective planning tool.

During the public health era (19th century USA, Great Britain and Australia) people with tuberculosis and people who engaged in criminal behaviour were both categorised as threats to society, and governments used early examples of Crime Prevention Through Environmental Design (CPTED) thinking to tackle both issues simultaneously. ${ }^{11}$ This paper argues that CPTED has various potential public health benefits for present and future generations.

\section{Crime Prevention Through Environmental Design}

CPTED, also known as Designing Out Crime, is a placebased strategy which argues that 'the proper design and effective use of the built environment can lead to a reduction in the fear of crime and the incidence of crime, and to an improvement in the quality of life'. ${ }^{12}$ It builds upon strategies of territoriality (sense of ownership), surveillance and access control and promotes activities within space including higher densities and mixed-use development in order to optimise the number of potential 'eyes on the street'. ${ }^{13}$ Evidence also supports the routine maintenance and management of urban space and the discouragement of the under-use of space (e.g. dereliction and/or vacancy) as crime prevention strategies. ${ }^{14-16}$ This 'image' element is also critical to CPTED. ${ }^{17}$ CPTED has application at the micro (building security), meso (street/neighbourhood) and macro (town/city) levels, where risk assessments and community participation are vital components of the CPTED process. CPTED is best applied at the design stage but is also used to modify existing urban environments. Research has reported positive reductions in levels of recorded crime and fear of crime for CPTED-style developments in the UK, ${ }^{18-21}$ and more recently a major international review of CPTED firmly demonstrates its efficacy as a crime prevention strategy. ${ }^{22}$

Criminological research has consistently indicated that crime is most prevalent in societies with significant disparities in the quality of life of its citizens, ${ }^{23,24}$ and within these societies crime and the fear of crime concentrates in specific places and at specific times. ${ }^{6,7}$ 


\section{Public health and crime}

Criminology and public health have traditionally focussed on the behaviour and characteristics of the individual. However, the fields of injury prevention and crime prevention both now recognise the importance of investigating the characteristics of the event itself. ${ }^{25}$

A large proportion of crime is dependent on the opportunities provided by the environmental setting. $7,10,26,27$ Increased levels of crime have been associated with locations where people congregate, including transit stations (rail and bus), drinking establishments and alcohol outlets, car parks and shopping malls. ${ }^{6,7}$ The environment can also affect opportunities for public health outcomes ${ }^{10}$ such as the proximity to playgrounds, ${ }^{28}$ walking and cycling amenities, ${ }^{28-30}$ alcohol outlets ${ }^{31}$ and the presence of boarded-up houses. ${ }^{15-17}$

Crucially, Wallace et al. ${ }^{32,33}$ have identified the deterioration of inner cities as contributing to the spread of HIV and tuberculosis, violence and a variety of health disparities and highlight the potential importance of the physical environment in reducing these opportunities and influencing health.

The current policy support for New Urbanism and the promotion of compact, high-density, mixed-use, walkable environments close to public transport clearly seeks to reduce the problems associated with urban sprawl such as car-dependency, congestion and pollution. These ideas also promote active living (e.g. walking) and seek to address the public health issues of sustainable development and the rising levels of obesity. CPTED has potential public health benefits by reducing opportunities for crime at the design stage to support initiatives to encourage walking and social activities.

A study by Cohen et al. ${ }^{34}$ suggested that one of the factors that should be considered in attempting to improve the health of communities is the level of physical deterioration of neighbourhood buildings - a central component of CPTED. Figure 1 illustrates how situational factors can affect health outcomes.

Crime is a mirror of the quality of the social environment and an indicator of community well-being, and 'physical conditions are not merely a consequence of social structures; rather, they are likely to be in dynamic relationship with social structures'. ${ }^{35}$

Indeed, the presence of surveillance opportunities does not necessarily ensure that surveillance is taking place and urban space can become 'undefended' ${ }^{36}$ by residents. As a result, Second Generation CPTED ${ }^{37}$ has recently evolved and seeks to engender positive social activities and diversity to encourage neighbours to take ownership of space and to take advantage of natural surveillance. This concept promotes neighbourhood capacity and community culture, cohesion and connectivity. ${ }^{38,39}$ CPTED is also being applied to products in order to reduce vulnerability to crime. ${ }^{40}$ The use of tempered glass to reduce violent incidents of 'glassing'41 is one example, which has obvious potential benefits for public health.

\section{Implementation and future direction in Australia}

At the national level, the Australian and New Zealand Crime Prevention Senior Officers Group has endorsed

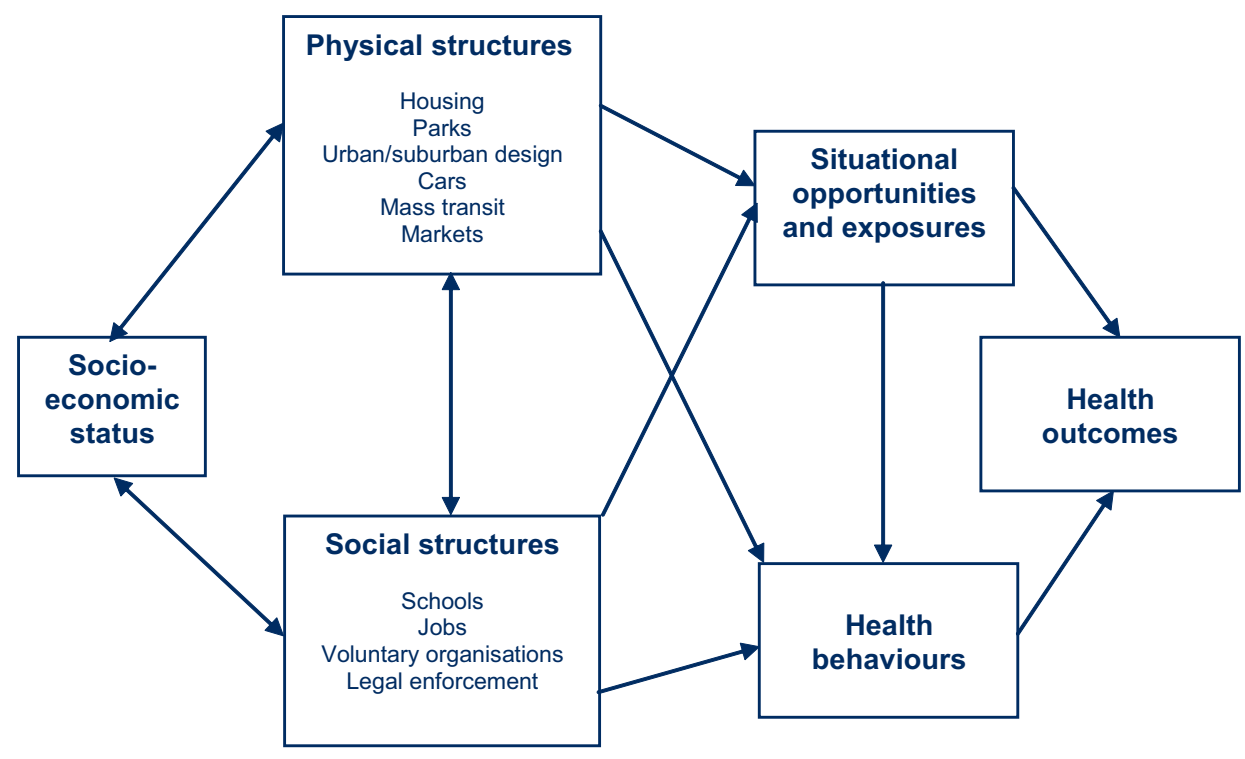

Figure 1. Environmental influences on health.

Source: Cohen DA, Mason K, Bedimo A, Scribner R, Basolo V, Farley TA. Neighborhood physical conditions and health. Am J Public Health 2003; 93:468. ${ }^{34}$ (Figure 1). Reprinted with permission from the American Public Health Association 
CPTED codes and principles and all states are implementing such programs. This national body is seeking to amend the Australian Building Codes and to embed CPTED principles within the planning process. This would ensure that the criminogenic potential of new urban developments is considered and minimised at the initial design stage. ${ }^{42,43}$

The national commitment to CPTED is arguably one example whereby the precautionary principle is being implemented. In WA, housing projections for 2031 estimate that 375000 new homes will be required ${ }^{44}$ and that most $(60 \%)$ will be built in existing urban areas. The publication of Designing Out Crime Planning Guidelines ${ }^{42}$ supported by Planning Bulletin No.7943 and a State Designing Out Crime Strategy (www.crimeprevention. wa.gov.au) to embed such ideas within the planning process and within product design clearly represent a commitment to development that will help to meet the needs of the present - and those of future generations. In New South Wales the Safer By Design ${ }^{45}$ program uses CPTED risk assessments and introduced Crime Prevention Legislative Guidelines to Section 79C of the Environmental Planning and Assessment Act (1979). This requires that authorities ensure that development provides safety and security to users and the community.

Significantly, the UK's Home Office has recently released a new crime strategy Cutting Crime: A New Partnership, ${ }^{46}$ which among other strategies, promotes CPTED. The report notes 'there are now over 100 documented case studies showing how crime has been reduced by

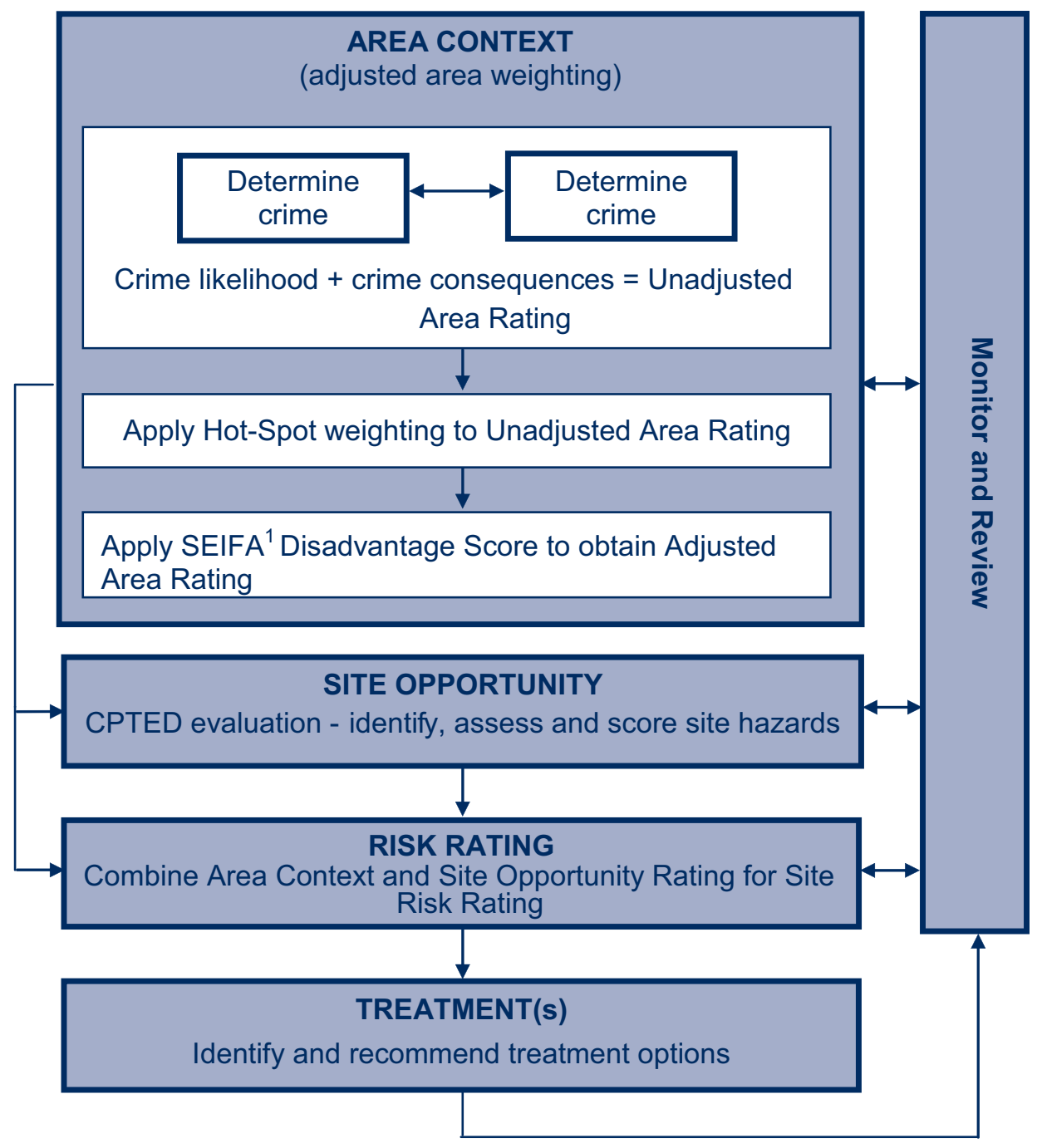

${ }^{1}$ SEIFA is a socio-economic index for communities developed by the Australia Bureau of Statistics.

Figure 2. Crime Prevention Through Environmental Design Crime Risk Evaluation Matrix. Source: adapted from McCamley P. Minimising Subjectivity: A New Risk Assessment Model for CPTED. The Journal of the International Crime Prevention Through Environmental Design Association 2002; 1(1): 25-34.54 
modifying places, products and services and removing the opportunities for theft, violence or vandalism. ${ }^{36}$

However, firm policy support for CPTED does not guarantee that CPTED is being implemented or that crime is being considered at the planning stage of the development process. Currently, the consideration of CPTED in Australia and the UK is largely optional for developers and crime risk assessments are not statutory (with the exception of NSW).

Environmental Impact Assessments (EIA) have been implemented in Australia since the early 1970s; however, human health considerations have been limited. ${ }^{47}$ Social Impact Assessments (SIA) are often carried out as part of, or in addition to, EIAs and seek to manage the intended and unintended social consequences of development. However, the International Principles Social Impact Assessment ${ }^{48}$ does not mention crime, and crime risk assessment is not part of the EIA process.

Health Impact Assessments (HIA) seek to predict the health impact of a development before implementation and early in the planning stage. The need for HIAs to be conducted explicitly in any environmental or economic decision-making process was strongly endorsed by the National Health and Medical Research Council in 1992. Crime is not part of the current HIA process.

Crime Risk Assessment (CRA) is not included in EIAs, SIAs or HIAs. In terms of HIAs for new developments, Northbridge and Sclar ${ }^{49}$ argue that "it is imperative to reinvigorate the historical link between planning and public health'. They discuss integrating urban planning and public health with other frameworks such as the ecosocial perspective, ${ }^{50}$ health and human rights,,${ }^{51}$ the precautionary principle ${ }^{52}$ and sustainable production ${ }^{53}$ to better understand and practise HIAs.

Until more formal CRA processes become available, the CPTED process represents a tool for assessing crime risk associated with new developments. Figure 2 illustrates a model developed by McCamley ${ }^{54}$ which 'employs qualitative and quantitative measures of the physical and social environment to create a contextually adjustable approach for the analysis and treatment of crime'.

Although it will be a challenging task, integrating existing assessment frameworks such as EIAs, SIAs, HIAs and CRAs represents a more holistic approach to assessing the multiple impacts of any development.

This paper argues the case for crime to be included in these frameworks and suggests CPTED is a useful process for conducting local CRAs and in reinvigorating the links between public health and urban planning.

\section{Conclusion}

CPTED is not a panacea, and although it does not guarantee that a city is safe from crime and the fear of crime, it can help create supportive physical environments for social and economic initiatives. ${ }^{55}$ It works best as part of a broad range of crime prevention strategies, which include the criminal justice system and both offender and victimfocussed approaches. Crucially, Brantingham and Brantingham ${ }^{7}$ have argued for a broader consideration of CPTED within planning, and likewise within the public health arena there are similar calls to consider place-based crime prevention strategies. ${ }^{10}$ McDonald ${ }^{56}$ has observed 'public health can make a valuable contribution to violence prevention and cover a much broader spectrum than can the criminal justice system alone.' As a proactive crime prevention strategy, CPTED represents a multidisciplinary approach that has application for public health, planning and crime prevention practitioners. CPTED also represents a process for collaboration across disciplines.

In the absence of any crime risk assessment model, CPTED represents a process for assessing local crime risk at the design stage. It can also reduce crime and fear of crime and contribute towards the design and management of urban space to support active living, walkability and public health.

\section{References}

1. Wirth L. Urbanism as a way of life. Am J Sociol 1938; 44: 1-24. doi:10.1086/217913

2. Napier M, Du Plessis C, Liebermann S, Kruger T, Shaw M, Louw A, Oppler S. Environmental design for safer communities in South Africa. Volumes 1 and 2. Pretoria: Council for Scientific and Industrial Research, 1998.

3. Vanderschueren F. Towards safer cities. UNCHS Habitat Debate. 1998; 4(1): 1-5.

4. Mayhew P. Counting the costs of crime in Australia. Australian Institute of Criminology Trends and Issues No. 247. Canberra: AIC, 2003.

5. Johnson H. Crime Victimisation in Australia: Key Results of the 2004 International Crime Victimisation Survey. Research and Public Policy Series No. 64. Canberra: Australian Institute of Criminology, 2005. At http://www.aic.gov.au/publications/rpp/64/rpp64.pdf, accessed 22 June 2006.

6. Brantingham PL, Brangtingham PJ. Environmental criminology. Beverly Hills, CA: Sage Publications, 1981.

7. Brantingham PJ, Brantingham PL. Environmental criminology: from theory to urban planning practice. Studies on Crime and Crime Prevention 1998; 7(1): 31-60.

8. Brantingham PJ, Brantingham PL, Molumby T. Perceptions of crime in a dreadful enclosure. Ohio J Sci 1977; 77(6): 256-61.

9. Vrij A, Winkel W. Characteristics of the built environment and fear of crime; a research note on interventions in unsafe locations. Deviant Behav 1991; 12: 203-15. 
10. Kawachi I, Kennedy B, Wilkinson R. Crime: social disorganisation and relative deprivation. Soc Sci Med 1999; 48: 719-31. doi:10.1016/S0277-9536(98)00400-6

11. Del Carmen A, Robinson MB. Crime prevention through environmental design and consumption control in the United States. The Howard Journal 2000; 39: 267-89. doi:10.1111/1468-2311.00168

12. Crowe T. Crime prevention through environmental design: applications of architectural design and space management concepts. 2nd ed. Oxford: Butterworth-Heinemann, 2000.

13. Jacobs J. The death and life of great American cities. New York: Vintage Books, 1961.

14. McKay T. Empty spaces, dangerous places. International crime prevention through environmental design association. At http://www.cpted.net/, accessed 25 October 2007.

15. Kraut DT. Hanging out the no vacancy sign: eliminating the blight of vacant buildings from urban areas. New York Univ Law Rev 1999; 74: 1139-77.

16. Ross CE, Mirowsky J. Disorder and decay: the concept and measurement of perceived neighbourhood disorder. Urban Aff Rev 1999; 34(3): 412-32.

17. Newman O. Defensible space people and design in the violent city. London: Architectural Press, 1973.

18. Armitage R. An evaluation of secured by design housing schemes throughout the West Yorkshire area. Huddersfield: University of Huddersfield, 1999.

19. Brown J. An evaluation of the secured by design initiative in Gwent, South Wales. MSc. Scarman Centre for the Study of Public Order, University of Leicester, 1999.

20. Pascoe T. Evaluation of secured by design in public sector housing. Final Report. Watford: BRE, 1999.

21. Cozens PM, Pascoe T, Hillier D. The policy and practice of secured by design (sbd). crime prevention and community safety Int J 2004; 6(1): 13-29.

22. Cozens PM, Saville G, Hillier D. Crime Prevention Through Environmental Design (CPTED): A review and modern bibliography. J Property Management 2005; 23: 328-56. doi:10.1108/02637470510631483

23. Kawachi I, Levine S, Miller S, Lasch K, Amick BIII. Income inequality and life expectancy; theory, research and policy. Joint Program on Society and Health Working paper series. Working Paper No. 94-2. Boston: New England Medical Center, 1994

24. Hsieh C, Pugh M. Poverty Income Inequality and Violent Crime: A Meta-analysis of Recent Aggregated Data Studies. Crim Justice Rev 1993; 18: 182-202. doi:10.1177/073401689301800203

25. Mair J, Mair M. CPTED and public health: a natural partnership. The Journal of the International Crime Prevention Through Environmental Design Association 2003; 2(1): 21-33.

26. Wilson JQ, Kelling GL. Making neighborhoods safe: sometimes 'fixing broken windows' does more to reduce crime than conventional 'incident-oriented' policing. Atl Mon 1989; 263(2): 46-52.

27. Felson M, Clarke R. Opportunity makes the thief. Practical Theory for Crime Prevention. Police Research Series Paper 98. London: Home Office Policing and Reducing Crime Unit. Research Development and Statistics Directorate, 1998.
28. Sallis JF, Bauman A, Pratt M. Environmental and policy interventions to promote physical activity. Am J Prev Med 1998; 15: 379-97. doi:10.1016/S0749-3797(98)00076-2

29. Ewing R, Cervero R. Travel and the built environment: a synthesis. Transport Res Rec 2001; 1780: 87-114. doi:10.3141/1780-10

30. Frank L. Land use and transportation interaction: implications on public health and quality of life. J Plan Educ Res 2000; 20(1): 6-22. doi:10.1177/073945600128992564

31. Speer P, Gorman D, Labouvie E, Ontkush M. Violent crime and alcohol availability: relationships in an urban community. J Public Health Policy 1998; 19(3): 303-18. doi: $10.2307 / 3343538$

32. Wallace R. Urban desertification, public health and public order: 'planned shrinkage,' violent death, substance abuse and AIDS in the Bronx. Soc Sci Med 1990; 31: 801-13. doi:10.1016/0277-9536(90)90175-R

33. Wallace R, Wallace D, Andrews H. AIDS, tuberculosis, violent crime and low birthweight in eight US metropolitan areas: public policy, stochastic resonance, and the regional diffusion of inner-city markers. Environ Plann A 1997; 29: 525-55. doi:10.1068/a290525

34. Cohen D, Mason K, Bedimo A, Scribner R, Basolo V, Farley T. Neighborhood physical conditions and health. Am J Public Health 2003; 93: 467-71.

35. Sampson RJ, Raudenbush S. Systematic social observation of public spaces: a new look at disorder in urban neighborhoods. AJS 1999; 105: 603-51. doi:10.1086/210356

36. Merry S. Defensible space undefended: social factors in crime prevention through environmental design. Urban Aff $Q$ 1981; 16(4): 397-422. doi:10.1177/107808748101600401

37. Saville G, Cleveland G. Second-generation CPTED in schools. In: 1st Annual International CPTED Association Conference, Orlando, FL. 1997.

38. Saville G, Cleveland G. An introduction to 2nd Generation CPTED: Part 1. CPTED Perspectives. 2003; 6(1): 7-9.

39. Saville G, Cleveland G. An introduction to 2nd Generation CPTED: Part 2. CPTED Perspectives. 2003; 6(2): 4-8.

40. Ekblom P. Gearing up against crime: a dynamic framework to help designers keep up with the adaptive criminal in a changing world. International Journal of Risk, Security and Crime Prevention. 1997; 2(4): 249-65.

41. Shepherd J, Hugget R, Kidner G. Impact resistance of bar glasses. J Trauma 1993; 36: 939.

42. WAPC. Designing Out Crime Guidelines. Perth: Western Australian Planning Commission, 2006. At www.wapc.wa.gov.au, accessed 25 October 2007.

43. WAPC. Designing Out Crime Planning Bulletin No.79. Perth: Western Australian Planning Commission, 2006. At www.wapc.wa.gov.au, accessed 25 October 2007.

44. Government of Western Australia. Hope for the future: the Western Australian State Sustainability Strategy. Perth: Department of Premier and Cabinet, 2003.

45. NSW Department of Urban Affairs and Planning. Crime prevention and the assessment of development applications Guidelines under section 79C of the Environmental Planning and Assessment Act 1979. Sydney: Crown Copyright, 2001. At 
http://police.nsw.gov.au/_data/assets/pdf_file/0003/9390/duap guide_s79c.pdf, accessed 25 October 2007.

46. Home Office. Cutting crime: a new partnership 2008-2011. London: Crown Copyright, Home Office, 2007.

47. Commonwealth Department of Health and Aged Care. Health Impact Assessment Guidelines. Canberra: Australian Government Department of Health and Ageing, 2001. At http://www.health.gov.au/internet/wcms/publishing.nsf/Content /health-pubhlth-publicat-document-metadataenv_impact.htm/\$FILE/env_impact.pdf, accessed 25 October 2007.

48. International Association for Impact Assessment. Social Impact Assessment: International Principles. Special Publication Series No. 2. 2003. At

http://www.iaia.org/modx/assets/files/SP2.pdf, accessed 25 October 2007.

49. Northbridge M, Sclar E. A joint urban planning and public health framework: contributions to Health Impact Assessment. Am J Public Health 2003; 93(1): 118-21.

50. Krieger N. Theories for social epidemiology in the 21st Century: an ecosocial perspective. Int J Epidemiol 2001; 30: 668-77. doi:10.1093/ije/30.4.668
51. Gruskin S, Tarantola D. Health and human rights. In: Detels R, McEwen J, Beaglehole R, Tanaka K, editors. The Oxford textbook of public health. 4th ed. New York: Oxford University Press Inc, 2001. pp. 311-335.

52. Kriebel D, Tickner J, Epstein P et al. The precautionary principle in environmental science. Environ Health Perspect 2001; 109: 871-6. doi:10.2307/3454986

53. Quinn MM, Kriebel D, Geiser K, Moure-Eraso R. Sustainable production: a proposed strategy for the work environment. $\mathrm{Am}$ J Ind Med 1998; 34: 297. doi:10.1002/(SICI)10970274(199810)34:4<297::AID-AJIM1>3.0.CO;2-Q

54. McCamley P. Minimising subjectivity: a new risk assessment model for CPTED. The Journal of the International Crime Prevention Through Environmental Design Association 2002; 1(1): 25-34.

55. Du Plessis C. The links between crime prevention and sustainable development. Open House International 1999; 24(1): 33-40.

56. McDonald D. No. 163. Violence as a public health issue. Trends and issues in crime and criminal justice. Canberra: Australian Institute of Criminology, 2000.

Erratum. In the Communicable Diseases Reports for July and August (N SW Public Health Bull 2007; 18(7-8): 145) and September and October (N S W Public Health Bull 2007; 18(9-10): 205), the data in the graphs 'Gastroenteritis outbreaks in institutions' are incorrect as the $x$-axis (year) was incorrectly labelled. The following corrections for these graphs should be noted.

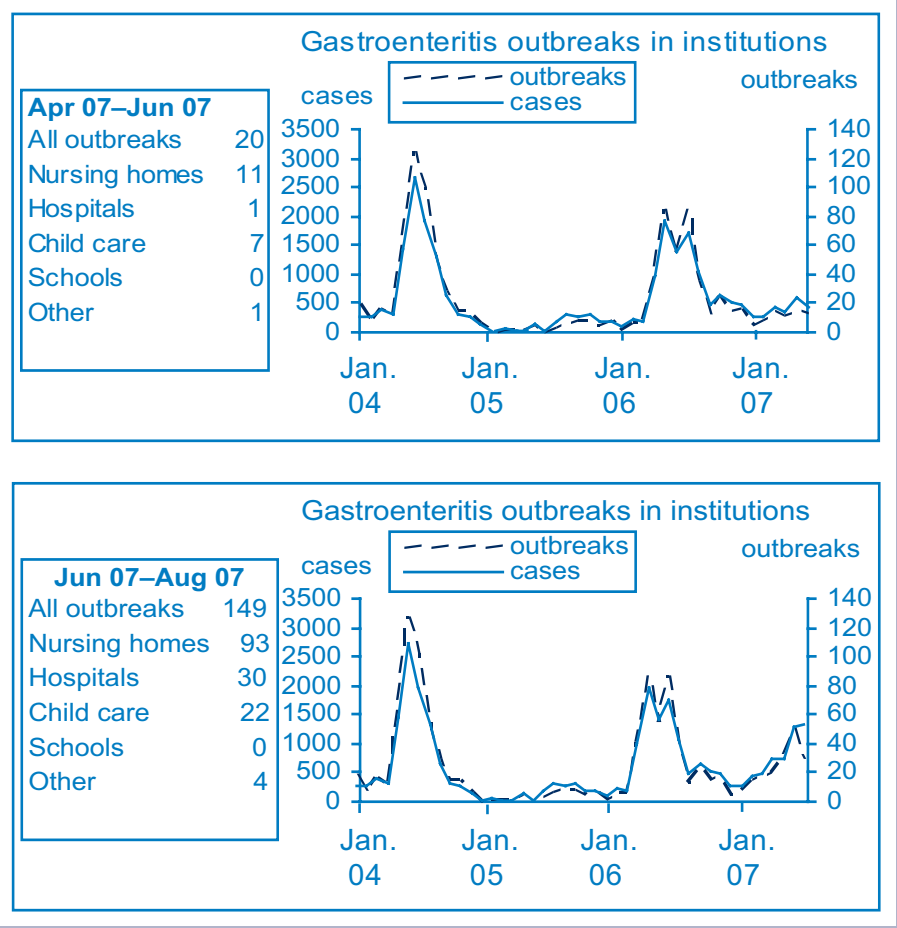

